\title{
A Century of Geological Investigation
}

A CONNECTED history of the work of the Geological Survey of Great Britain has long been overdue. It is true that many details can be gathered from the lives of Edward Forbes, Murchison and Ramsay, from Geikie's "Long Life's Work", and from the registers of the Royal School of Mines and the Royal College of Science. But what was wanted was an impersonal account of the service and its work, written from the point of view of the service itself; and that has now been furnished by Sir John Flett in "The First Hundred Years of the Geological Survey of Great Britain"*. It was the last act of his thirty-five years' service, during fifteen of which he was director, and for another ten assistant to the director for Scotland. It marks the centenary in 1935 of the Survey, and the opening of the new Geological Museum at Kensington by H.R.H. the Duke of York, now His Majesty King George VI.

The author has succeeded in making a clear statement of the complicated history of the Survey itself, and the other institutions now or formerly a part of it or very closely associated with it. $\mathrm{He}$ directs attention to the demand for such an institution on the part of the mineral industries of the country and the influence of famous geologists and of the Geological Society, which caused the idea of a State survey to be accepted and even welcomed by the authorities of the time. He has indicated in due proportion the share in the mapping and description of the country taken by the leading geologists of the Surveys. And he has enabled the reader to form a fair judgment on the progress effected as a result of royal commissions and committees of inquiry, and by the successive directors in the favourable or unfavourable conditions prevailing during their periods of office.

It is impossible to speak too highly of the work and influence of the first director-general, Sir Henry De la Beche, appointed in 1835, after he had offered, at trifling cost, to "affix geological colours" to the new maps of Devon and Cornwall about to be issued by the Ordnance Survey. He set himself to do four things which he considered to be essential at the time, and which he saw could be carried out, at first at any rate, by a State Survey as he conceived it : (1) The mapping and description of the geology of the country, especially in relation to its mineral resources; (2) the collection and preservation in some accessible

* The First Hundred Years of the Geological Survey of Great Britain. By Sir John Smith Flett. Pp. $280+13$ plates. (London : H.M. Stationery Office, 1937.) 78. 6d. net. place of the evidence on which such work is founded, the records of the work as it advanced, the literature necessary for proper working up of the material, and specimens to illustrate the geology and mineral resources; (3) the education and training of men capable of doing the work or of directing the development of the mining industries; (4) the collection and preservation of mining statistics and records, especially so far as they are necessary to guide future exploitation. The first two objects have remained and grown as the special care of the Survey; the other two sooner or later budded off and are now living separate and vigorous lives of their own.

It being essential first to acquire an exact knowledge of the ground-work, the geological nature and structure of the land, attention was concentrated on mapping, with a remarkable team which grew steadily in strength. The director himself and his assistants, among whom Aveline, Ramsay, Jukes, Logan and Selwyn were leaders, worked at high speed and with an accuracy which is wonderful when it is considered that only oneinch maps, uncontoured and often unsatisfactory in topography, were all that were available for either field-work or publication. Maps were supplemented by 'horizontal' sections (illustrated by explanations) along specially surveyed routes, and by 'vertical' sections on a large scale giving full detail of thoroughly explored ground. More maps and sections were published under this régime than at any later time. Little leisure, however, was left for writing, and few memoirs were published, those put out being mainly essays on scientific subjects, or descriptions of considerable regions, such as the South Staffordshire coalfield by Jukes.

A museum was opened at Craig's Court in 1841, but ten years later the Prince Consort opened its successor, the Museum of Practical Geology at Jermyn Street, where the collections and workers were housed for eighty years. This "was the first important building in Great Britain designed to be occupied by the staff of a purely scientific institution". The Museum was intended to be definitely national, economic and practical, and in time these objects came to overshadow the scientific side, for example, in the large and valuable collections of metal work and pottery. For these, new and more appropriate sites were found soon after 1901, and room was thus provided for the more direct applications of geology. A distinguished staff was employed in the Museum 
and in expert work in connexion with the mapping. It included such men as Hooker, Forbes, Phillips and Playfair (afterwards Lord Playfair), Percy, Hunt, Warington Smyth and Huxley.

Several of the staff were employed as professors in the School of Mines, which had its home also at Jermyn Street. In spite of this work and their routine duties for the Survey and Museum, time was found for the issue of works on fossils (Decades and Monographs), of memoirs on the economic or other geology of districts, and for the delivery of technical lectures and of more popular lectures for working men. The desire of the Prince Consort, who had given whole-hearted support to the plans, to see the School of Mines grow into a more comprehensive scheme for scientific and technical education was thought premature by De la Beche and his successors, and was indeed not fully brought about until 1910, when the Royal School of Mines, the Royal College of Science and the City and Guilds Engineering College were incorporated as the Imperial College of Science and Technology. The School of Mines was, however, largely by Huxley's influence, removed to South Kensington between 1872 and 1883, and many of the books were taken from the library to form the basis of the Science Library there.

Sir Roderic Murchison, as director-general, brought to the institution from outside great organizing ability and valuable social influence. His work (1855-71) was mainly comprised within the framework of his predecessor's scheme, but he strengthened the administration and inspection, and brought about a much-needed increase in staff. All De la Beche's plans of publication were continued, but there was inaugurated the issue of memoirs on individual map sheets, and on several coalfields on which the mapping was being concentrated, while museum handbooks and district memoirs were added to those already published, including Ramsay's great memoir on North Wales. The first index map, of Wales and its borders, on the quarter-inch scale, was also published.

The appointment of Sir Andrew Ramsay as director-general in 1871 illustrates one of the difficulties that have been inherent in the Survey. The duties of inspection, reporting and administration are so heavy that a director must practically abandon all his own field-work, and thus the field staff loses both an inspiration and a standard. Ramsay was certainly one of the finest fieldmen who ever lived and his loss was most serious in this capacity. Fortunately it proved that his organizing powers were also considerable, but the work speedily wore him out. Under his direction, the first 'drift' maps were prepared, new museum catalogues and handbooks were issued, very valuable collections were acquired by the Museum, such as the Ludlam collection of 20,000 minerals, and some of the most important memoirs ever written were published, among them that on the Yorkshire coalfield, and those on London, Rutland, and the Weald. The Survey being, up to this date at least, the principal training ground for professional geologists, had to face the inevitable loss of some of its best men to fill teaching posts in universities and colleges and to assume the direction of other surveys.

Sir Archibald Geikie, who had been a member of the Survey for twenty-six years, a great part of that time in sole charge in Scotland as well as professor at Edinburgh, was appointed directorgeneral in 1882, and served in that capacity for twenty years. In accordance with his undertaking, the 'solid' map of England was finished by 1884, and that of Ireland four years after. A 'drift' survey, of as great value to the agriculturist as the 'solid' maps are to the miner, now chiefly claimed attention, and as maps were revised for this purpose they were also brought up to date on the 'solid' side. This entailed the publication of a large number of maps, many of which were now accompanied by sheet memoirs. Some district memoirs, a few on coalfields, the first one on waterresources, and the first complete index map on England and Wales, were also published. But the chief departure, one abandoned by his successors, was the issue of memoirs devoted to individual formations-Jurassic, Cretaceous, etc. Petrology was now put on a level with palæontology, and specialists were appointed. Teall was brought in to deal with Scottish, and particularly Highland, rocks, and Harker to map and describe the Tertiary igneous complex of Skye. Much was done to exhibit Survey material worthily in museums at Edinburgh and Dublin, and the customary "Annual Report" was converted into a "Summary of Progress", containing some account of the chief discoveries made during the year This "Summary" has now also become a magazine for communications by the staff. A start was made with the muchneeded revision of the coalfields, among others that of South Wales, which was put in charge of Strahan. It expresses the state to which grading and organization in the service had sunk when it is realized that the officer chosen for this highly responsible task was still an 'assistant-geologist' after sixteen years' service, and that he had under him men who had been full 'geologists' for more than twenty years.

The very considerable improvements in organization recommended by the Wharton Committee of 1900 took effect in the appointment in 1901 of Sir Jethro Teall as director, and a new grading and enlargement of the staff. This inaugurated a period of renewed activity. Much coalfield 
revision, recommended by the Coal Resources Commission, was carried out in England and Scotland, and many coalfield, coal-chemistry, oil-shale, water and sheet memoirs were published. Field-work was now all executed on the six-inch scale, and the revision published on the 'New Series' ordnance maps. Colour printing replaced the old hand colouring on all one-inch maps, the quarterinch index, and the new small-scale map of the entire kingdom. Thus maps were cheapened and made available to a much larger public, and it became possible to supply them in quantity at a reduced price for educational purposes. Vertical and horizontal sections were also printed on the map margins. The publication of palæontological monographs was resumed, and the district memoirs included the great works on Skye, the Highlands and Lowlands of Scotland, and the Isle of Man. Much use was made of photography for illustration as well as in the Museum, and the removal of extraneous collections and of the lecture hall gave fresh space for developing the modified purposes of the building. The Survey of Ireland was separated in 1908, after a series of new drift maps had been published under Lamplugh's direction.

The directorship of Sir Aubrey Strahan (1914-20) was crippled by the Great War, the staff being largely called on for service. What remained of them brought out the publications that were on the stocks and then, with some voluntary help, devoted themselves to writing a new series of memoirs dealing with the mineral resources of the country, many of them seriously needed to replace supplies from abroad now cut off. Water problems and other geological ones at the seats of war were met by members of staff in the army or at home, and special search was made for sources of such things as sand, quartz, oil, refractories, fluorite, sapphire, etc., needed for munitions. At the end of the War, the Survey was taken over from the Board of Education by the new Department of Scientific and Industrial Research; and a Geological Survey Board was formed to assume the duties formerly discharged by a Committee of Advice.

Sir John Flett does not give very full details in his book of the progress under his own directorship, but much can be gleaned of efficiency and progress from what is stated. The staff was enlarged, publication of sheet memoirs and maps was pushed on more actively than even before, the resources memoirs were brought up to more than thirty, coalfield and water memoirs continued to appear, monographs and vertical sections were resumed, and experiments were made on the applications of geophysical apparatus. Uncoloured six-inch maps with geological lines prepared from the field sheets were rendered available.
Co-operation was given to Boards of Fuel and Building Research, to the Inland Water Survey, to the search for oil, and to the making of soil-maps. New rights to information revealed by shafts and borings were acquired, the careful collection of kindred information, often confidential, was continued, and the relations of mutual respect and confidence with the managers of mining and other industrial operations were strengthened. A successful experiment on decentralization was tried, and four centres in the north of England were established. The publication of the last of the great series of memoirs on the Scottish Tertiary volcanic centres contributed what is perhaps the most important addition ever made to knowledge of active as well as extinct volcanoes ; and memoirs on concealed coalfields give leading to fresh industrial development.

Meanwhile, probably as a result of the explosion of an aerial bomb in Piccadilly, the Museum had fallen into irreparable disrepair, and much of it had to be closed. When it was clear that repair was out of the question, the Survey Board, and especially its chairman, Sir Francis Ogilvie, seconded by the Museums Commissions, pressed on the Government the need for a new museum. Eventually a site was found and a new building erected, the site of the old one proving so valuable that it may be even said the change was an actual source of profit, a last legacy of the far-seeing De la Beche. The director and his staff carefully planned the utilization of the increased space provided, removed and replaced all the collected material, and devised methods of storage, illustration and display which have given fresh uses and great popularity to the new Museum.

An account is given at the end of the book of the opening of the new Museum and the celebration of the Survey centenary, which were attended by a large concourse of Government and scientific delegates, who came from all parts of the country and all over the world to bring their congratulations and commendation. A group photograph of the delegates and a full list of them are given in an appendix. Other appendixes give a bibliography and a carefully prepared list of nearly three hundred Survey officers who could be traced, with brief notes on their service and career. This list contains the names of four presidents of the Royal Society.

Thus the Survey makes an auspicious and hopeful beginning of its new century, and the author of this work and his colleagues, past and present, are to be congratulated on such a worthy record of a hundred years of sound and faithful work, a justification of the hopes and ambition of its originator, and a valuable asset to the industrial life of the nation.
W. W. WATTS. 